\title{
The Use of ICD-10 for Diagnosing Mental Disorders In Russia, According to National Statistics and a Survey of Psychiatrists' Experience
}

\author{
Использование МКБ-10 для диагностики психических расстройств в России: по \\ данным государственной статистики и результатам опроса врачей \\ doi:10.17816/CP69
}

\section{(C) Ivan A. Martynikhin}

Department of Psychiatry and Narcology, the First Saint-

Petersburg State Medical University, Saint-Petersburg, Russia

\author{
(C) Иван А. Мартынихин \\ Кафедра психиатрии и наркологии, Первый Санкт- \\ Петербургский государственный медицинский \\ университет имени академика И.П. Павлова, \\ Санкт-Петербург, Россия
}

\begin{abstract}
Purpose and methods. In order to assess the specifics of practical use of the ICD-10 Diagnostic Guidelines by Russian psychiatrists, official national statistics on the prevalence of a number of mental disorders in Russia in 2019 were compared with the results of meta-analyses of international epidemiological studies of these disorders. In addition, a number of items in the online psychiatrists' survey, relating to the diagnosis of schizophrenia, were analysed; 807 Russian psychiatrists took part in the online survey.
\end{abstract}

Results. Analysis of national statistics showed that domestic clinicians diagnose some mental disorders significantly less often than might be expected, according to data obtained by international epidemiological studies. The number of cases of bipolar affective disorder registered in Russia is $90-150$ times less than that for the prevalence of this disorder, according to meta-analyses of epidemiological studies; for depression, the result is 50-70 times; for anxiety disorders, the number is 25-50 times, and for autism, it is 30 times. Instead of the above disorders, diagnoses of organic non-psychotic mental disorders and schizophrenia might have been used unreasonably often. Between 2005 and 2019, diagnosis of childhood autism changed significantly (an increase of more than 100\%), while the frequency of diagnosing other mental disorders remained unchanged. The results of the online survey also showed largely perfunctory use of the ICD-10 Diagnostic Guidelines, with a third of respondents reporting never checking the diagnostic schedules, and another third doing so from time to time. In addition, the low estimates given by survey participants regarding practical utility of the ICD-10 Diagnostic Guidelines, along with a large percentage of respondents who do not directly use diagnostic criteria in their work, indicate the need to improve the clinical usefulness of the diagnostic guidelines in the latest revision of the ICD, including convenience of use in practice.

Conclusion. The results of analysis of the Russian national mental health service statistic indicate that at least some diagnostic categories are not used by Russian psychiatrists exactly as ICD-10 suggests. The revealed discrepancy between the principles of diagnostics observed by domestic clinicians and international criteria may interfere with the use of evidence-based treatment algorithms, negatively affecting the quality of psychiatric care. In light of the upcoming transition to ICD-11 and in order to unify approaches to the diagnosis of mental disorders in our country, it is necessary to update and improve educational programmes for psychiatrists. 


\section{АНнОТАЦИЯ}

Цель и методы. С целью оценить особенности практического использования российскими психиатрами диагностических руководств к МКБ-10 было проведено сопоставление официальной государственной статистики о распространенности ряда психических расстройств в России в 2019 г. с результатами метаанализов международных эпидемиологических исследований данных расстройств. Дополнительно проведен анализ ряда пунктов онлайн-опроса психиатров о диагностике шизофрении. В онлайн-опросе принимало участие 807 российских психиатров.

Результаты. Анализ данных государственной статистики показывает, что отечественные клиницисты диагностируют некоторые психические расстройства существенно реже, чем этого следовало бы ожидать, исходя из данных международных эпидемиологических исследований. Так, количество зарегистрированных в России случаев биполярного аффективного расстройства в 90-150 раз меньше, чем распространенность этого расстройства по данными мета-анализов эпидемиологических исследований; депрессии - в 50-70 раз; тревожных расстройств - в 25-50 раз, аутизма - в 30 раз. Вместо этих расстройств неоправданно часто могут использоваться диагнозы органических непсихотических психических расстройств и шизофрении. За период 2005-2019 гг. существенно изменилась диагностика детского аутизма (рост более, чем на 100\%), тогда как частоты диагностики других психических расстройств остались без существенных изменений. Результаты онлайн опроса также продемонстрировали во многом формальное использование диагностических руководств к МКБ-10: треть респондентов никогда не сверяется с диагностическими перечнями, треть - делает это время от времени. Кроме того, низкая оценка участниками опроса утилитарных свойств диагностического руководства К МКБ-10 и большой процент респондентов, которые не используют непосредственно диагностические критерии в своей работе, указывают на необходимость улучшения клинической полезности диагностического руководства новой версии МКБ, включая удобство его практического использования.

Выводы. Результаты анализа статистики российской государственной психиатрической службы свидетельствуют о том, что как минимум ряд диагностических категорий российские психиатры используются не совсем так, как предполагает МКБ-10. Выявленное несоответствие принципов диагностики, проводимой отечественными клиницистами, современным международным критериям может мешать применению доказательных алгоритмов терапии, негативно влияя на качество психиатрической помощи. В свете грядущего перехода к МКБ-11 и с целью унификации подходов к диагностике психических расстройств в нашей стране, необходимо обновление и усовершенствование образовательных программ для психиатров.

Keywords: ICD-10; diagnosis; epidemiology of mental disorders; survey

Ключевые слова: МКБ-10; диагностика; эпидемиология психических расстройств; опрос

\section{INTRODUCTION}

Since 1999, by Order of the Ministry of Health of the Russian Federation, Russian health authorities and institutions have moved towards use of the International Statistical Classification of Diseases and Related Health Problems, $10^{\text {th }}$ version (ICD-10), when "preparing statistical reports". ${ }^{1}$ Since this time, published national statistics on the incidence of mental disorders in Russia have been based on ICD-10 diagnoses. However, the issue of how fully and consistently (in practice) Russian psychiatrists follow the criteria of the diagnostic guidelines prepared by the World Health Organization in the ICD-10 chapter on mental disorders remains open to this day.

During the Soviet period, psychiatry in our country was largely isolated from international practice. Many of the ICD-10 provisions, which suggested a revision of the previously dominant nosological approach and a transition to operational criteria, were completely new for Russian psychiatrists and were criticized by many colleagues who were used to working with a substantially abridged Soviet Union version of ICD-9. 
These aspects make it relevant to assess the specifics of practical application of the ICD-10 criteria by Russian psychiatrists. For the said purpose, we: a) compared official national statistics on the prevalence of mental disorders in Russia with the results of meta-analyses of international epidemiological studies on a number of mental disorders; and b) conducted a large-scale online survey of psychiatrists on specific use of ICD-10 in their practice (in relation to the diagnosis of schizophrenia).

In Russia, free medical (including psychiatric) care is guaranteed by the Constitution of the country. Most medical institutions are state-owned, subordinate to the Ministry of Health, and annually provide the Ministry with statistical data on patients treated. Statistical compilations are made on the basis of these reports. The most recent compilation, which contains detailed statistics on the ICD-10 categories of mental disorders, includes data ${ }^{2}$ for
2019. The same team of authors published a compilation of data for 2005-2013, using a similar methodology. ${ }^{3}$

\section{METHODS}

We selected a number of disorders (or groups thereof) from different sections of the ICD-10 mental disorders chapter, in the context of which the specifics of the use of this classification in our country are most noticeable (Table 1). For disorders with available, valid international epidemiological studies and meta-analyses, we have provided a comparison of the frequency of diagnosing such disorders (as observed in our country) and the expected rates (based on the results of relevant studies).

A large-scale online survey of Russian psychiatrists on approaches to diagnosis of schizophrenia was conducted on the website of the Russian Society of Psychiatrists (RSP) in 2016. The survey methodology

Table 1. Comparison of Russian national statistics on the prevalence of a number of mental disorders with data from international epidemiological studies

\begin{tabular}{|c|c|c|c|}
\hline Diagnosis & $\begin{array}{l}\text { National statistics of the Russian } \\
\text { Federation: the number of registered } \\
\text { patients per year (\% of the Russian } \\
\text { population) })^{2}\end{array}$ & $\begin{array}{l}\text { Data from meta-analyses } \\
\text { of population-based studies - } \\
\text { incidence rate per year } \\
\text { (\% of the population) }\end{array}$ & Discrepancy ratio \\
\hline Schizophrenia & $\begin{array}{l}F 20-0.32 \% \\
\text { (entire section F20-F29 - 0.36\%) }\end{array}$ & $0.33 \%^{4}$ & $1: 1$ \\
\hline Bipolar affective disorder & $0.0081 \%$ & $\begin{array}{l}1.21 \%(0.71 \text { for BAD type } 1 \text { and } 0.50 \\
\text { for BAD type } 2)^{5}\end{array}$ & $1: 90-1: 150$ \\
\hline Depression & $\begin{array}{l}\text { All affective disorders, excluding bipolar } \\
\text { affective disorder - } 0.083 \%\end{array}$ & $\begin{array}{l}\text { Depression }-3.7 \% \text { of the population } \\
\text { per year (in cross-sectional studies } \\
-4.7 \% \text {, and for eastern European } \\
\text { countries }-5.1 \%)^{6}\end{array}$ & $1: 50-1: 70$ \\
\hline Anxiety disorders & No data, but the entire section $\mathrm{F} 4-0.3 \%$ & Group of anxiety disorders $-6.7 \%^{7}$ & $1: 25-1: 50$ \\
\hline Autism & $0.025 \%$ & $0.76 \%^{8}$ & $1: 30$ \\
\hline $\begin{array}{l}\text { Organic non-psychotic } \\
\text { mental disorders }\end{array}$ & $0.66 \%$ & No studies available & \\
\hline $\begin{array}{l}\text { Dementia in Alzheimer's } \\
\text { disease }\end{array}$ & $\begin{array}{l}\text { Old-age dementia }-0.03 \% \text { Among people } \\
\text { over } 60 \text { years of age }-0.14 \% \text { of the } \\
\text { population }\end{array}$ & $3.9 \%$ of people over 60 years of age ${ }^{11}$ & $1: 25-1: 30$ \\
\hline Vascular dementia & $\begin{array}{l}0.09 \% \text {. Among people over } 60 \text { years } \\
\text { of age }-0.46 \% \text { of the population }{ }^{9}\end{array}$ & $\begin{array}{l}\text { No available studies in populations } \\
\text { corresponding to the Russian ones }\end{array}$ & \\
\hline
\end{tabular}


and results have been described in detail in previous publications. ${ }^{11}$ Firstly, the questionnaire was sent out in personal letters to psychiatrists registered on the RSP website (https://psychiatr.ru), and these invitations led to 616 respondents participating in the survey. At the end of the first stage of the survey, a public link to the questionnaire was posted on the RSP website. During the second stage, another 191 psychiatrists took part in the survey. Thus, a total of 807 Russian doctors (who had completed core training in psychiatry across 78 regions of Russia) became survey participants (with a third of respondents representing the largest cities in Russia, namely Moscow and St. Petersburg). The survey was completed in full by 621 respondents (76\%); i.e., all questions in the questionnaire were answered (not taking into account sections for additional comments). The median work experience in the specialty was 15 years; $33 \%$ of the participants were hospital employees; $39 \%$ were employees of outpatient and consultative units; $25 \%$ were scientific, teaching or administrative staff; and $28 \%$ of the respondents had an academic degree. When compiling and conducting the survey, the selectivity approach was used. In this case, the first question was "Do you use ICD-10?", followed by "Do you conduct a diagnostic procedure for new patients with psychotic disorders?". Then there was the question of how exactly the ICD-10 diagnostic criteria for schizophrenia are used to diagnose schizophrenia. Those who do not use ICD-10 and those who do not work with new patients with psychosis were excluded from our analysis of this question.

\section{RESULTS}

According to statistics, in 2019, more than 3.93 million people applied to the psychiatric service due to mental disorders (i.e., $2.68 \%$ of the Russian population). State healthcare provision units registered 465 thousand patients with schizophrenia (F20), or $0.32 \%$ of the population. (Section F20-29 in its entirety accounted for $0.40 \%$.) This frequency almost exactly corresponds to the results of a meta-analysis of epidemiological studies of schizophrenia prevalence, conducted between 1965 and 2002. ${ }^{4}$ Patients with schizophrenia accounted for $12 \%$ of all people who turned to Russian state institutions for psychiatric care in 2019.

A total of 120 thousand people (or $0.082 \%$ of the population) sought psychiatric care for affective disorders. Among those registered, only 12 thousand people had bipolar affective disorder (BAD; including psychotic and non-psychotic episodes), or $0.008 \%$ of the population. A systematic review and meta-analysis of epidemiological studies indicates that the annual prevalence of BAD is $1.21 \%$ of the population, of which $0.71 \%$ is $B A D$ type $\mathrm{I}$, and $0.50 \%$ is BAD type $11 .{ }^{5}$ Since ICD-10 does not distinguish between types I and II of BAD, it can be assumed that Russian data correlate to a greater extent (but not completely) with the prevalence of BAD type I. Thus, the difference in prevalence ranges from 90 (when compared only with the prevalence of BAD type I) to 150 times (when compared with the overall prevalence of $B A D$ ).

Unfortunately, the exact number of people who have sought medical care for depression is not given in statistical compilations, but assuming that the overwhelming majority of all those who were treated for affective disorders in 2019 (minus those with BAD) suffered from depression, it can be seen that no more than 108 thousand people with depression (or $0.074 \%$ of the population) sought help from Russian state psychiatric institutions. A systematic review of epidemiological studies shows that depression diagnosis rates in Russia do not reflect the prevalence in the general population, where depression is significantly more widespread: $3.7 \%$ of the population suffered from depression within a year; $4.7 \%$ of the population had depression in cross-sectional studies. ${ }^{5}$ There is no reason to assume that the incidence of depression in Russia for any reason is less than the global average. Moreover, the authors of the review suggest that the prevalence of depressive disorders in eastern Europe is slightly higher than in the rest of the world (5.1\% of the population in cross-sectional studies). Thus, the difference in prevalence ranges from 50 (when compared with a prevalence of $3.7 \%$ of the population) to 70 times (when compared with a prevalence of $5.1 \%$ of the population).

One of the most common mental disorders in the population, along with affective disorders, is anxiety disorder. ${ }^{7}$ Unfortunately, national statistics do not account for this group of disorders separately, but there are data for the whole of section F40-F48 (neurotic, stress-related and somatoform disorders). The total number of people who sought medical care and were diagnosed with disorders from this section was 403 thousand people, or $0.27 \%$ of the population $(10 \%$ of all those seeking psychiatric help). A systematic review and meta-analysis 
of epidemiological studies ${ }^{7}$ showed the annual incidence of anxiety disorders to be $6.7 \%$ among the population. At the same time, the authors attributed the following categories to this group of disorders: generalized anxiety disorder, panic disorder, agoraphobia, social phobia, obsessive-compulsive disorder, post-traumatic stress disorder and acute stress disorder. Thus, the difference in prevalence ranges from 25 (when compared with all individuals with section F4 diagnoses) to 50 times (if suggested that the disorders considered in this metaanalysis account for about half of all section F4 diagnoses).

In 2019, 36.6 thousand people, or $0.025 \%$ of the Russian population, were diagnosed with childhood autism. The meta-analysis of epidemiological studies indicates that the prevalence of autism diagnosed according to current criteria globally is $0.76 \% .{ }^{8}$ Thus, the difference in frequency is 30 times.

In particular, we should mention the organic nonpsychotic disorders section of the statistical compilation. In total, in 2019, more than 965 thousand people (almost a quarter of all those who were treated), or $0.66 \%$ of the population, sought help for disorders in this group. Dementia turned out to be a relatively rarely used diagnostic category in the Russian psychiatric service; 182 thousand people $(0.12 \%$ of the population) with diagnoses of "Vascular dementia and other forms of old-age dementia" were under observation. Of these, 133 thousand (73\% of all patients with dementia) were diagnosed with vascular dementia, and the remaining 48 thousand were diagnosed with "other forms of dementia". Similar figures are given by selective publication of statistics on the prevalence of mental disorders among people over 60 years of age. ${ }^{9}$ In 2016, 123 thousand people with vascular dementia and 43 thousand with old-age dementia were observed. (We are providing data for 2016 here as more recent data have not yet been published.) According to the literature sources, the most common cause of old-age dementia is Alzheimer's disease, which has a prevalence of about $3.1 \%$ of the population over 60 years of age in eastern Europe. ${ }^{10}$ Taking into account the fact that, in Russia, about $22 \%$ of people are over 60 years of age (data from the Federal State Statistics Service), the difference in the frequency of diagnosis ranges from 25 (if Alzheimer's disease is taken as the cause of all old-age dementias) to 30 times. (Alzheimer's disease is the most common but not the only cause of dementia in this group of people.)
Unfortunately, epidemiological studies of the prevalence of vascular dementia in populations with similar gender, age composition and risk factors are not sufficient for the purposes of comparing diagnosing frequency.

Table 2 shows the dynamics of registered cases of the above-mentioned disorders between 2005 and 2019.,3 The bipolar affective disorder category and the division into vascular and old-age dementias have only been included in statistical compilations since 2010. Accordingly, for those categories that were included in the 2005 data compilation, the table shows the percentage change of the number of registered cases to the number of cases treated in 2005, for those for which the data are available, starting only from 2010 the percentage change to the number of cases treated in 2010. According to the data provided, the total number of patients registered by psychiatric units and institutions over the past 14 years has decreased by almost $7 \%$, and the number of people who sought help for most of the disorders considered has also decreased, with the exception of those with disorders falling into the categories of organic non-psychotic mental disorders $(+7.8 \%)$ and vascular dementia $(+4.7 \%)$. The greatest decrease in the number of reported cases was observed for patients with depression (-16.3\%) and neurotic, stressrelated and somatoform disorders (-28.6\%).

The results of the psychiatrists' survey on use of the ICD-10 Diagnostic Guidelines in the diagnosis of mental disorders showed that most respondents (96\%) use ICD-10 codes in their practice, of whom $86 \%$ indicated that they specify a detailed (accurate) diagnosis and code for the disorder, with $9 \%$ only making a generalized diagnosis (for example, F20 for schizophrenia, without specifying the form and course of the disease). At the same time, of those who use the ICD-10 codes, only $14 \%$ check the ICD-10 Diagnostic Guidelines ${ }^{12}$ for each schizophrenia diagnosis. Almost a third of respondents (29\%) never check the schedule; a little more than a third (36\%) check only occasionally (in difficult diagnostic cases); and $21 \%$ often check the schedule (Figure 1).

The respondents' average estimate of the usability of the ICD-10 diagnostic criteria schedule for schizophrenia, on a scale from one to five, was 3.44, and the correspondence with their clinical practice was 3.66. However, for specific items in the diagnostic criteria schedule for schizophrenia, most respondents (67\%) were in favour of maintaining the schedule in its current 


\begin{tabular}{|c|c|c|c|c|c|c|c|c|}
\hline \multirow[t]{2}{*}{ Diagnosis } & \multicolumn{2}{|l|}{2005} & \multicolumn{2}{|l|}{2010} & \multicolumn{2}{|l|}{2019} & \multicolumn{2}{|c|}{$\begin{array}{l}\text { Dynamics from } 2005 \\
\left(2010^{*}\right) \text { to } 2019\end{array}$} \\
\hline & $\begin{array}{l}\text { abs. } \\
\text { number }\end{array}$ & $\begin{array}{l}\% \text { of } \\
\text { population }\end{array}$ & $\begin{array}{l}\text { abs. } \\
\text { number }\end{array}$ & $\begin{array}{l}\% \text { of } \\
\text { population }\end{array}$ & $\begin{array}{l}\text { abs. } \\
\text { number }\end{array}$ & $\begin{array}{l}\% \text { of } \\
\text { population }\end{array}$ & $\begin{array}{l}\text { abs. } \\
\text { number }\end{array}$ & $\begin{array}{l}\text { Percentage } \\
\text { from } 2005 \\
\left(2010^{*}\right)\end{array}$ \\
\hline $\begin{array}{l}\text { Total patients } \\
\text { registered by the } \\
\text { service }\end{array}$ & $4,223,694$ & 2.937 & $4,187,873$ & 2.932 & $3,934,058$ & 2.680 & $-289,636$ & $-6.9 \%$ \\
\hline Schizophrenia & 515,712 & 0.359 & 502,883 & 0.352 & 464,761 & 0.317 & $-50,951$ & $-9.9 \%$ \\
\hline Affective disorders & 138,206 & 0.096 & 141,994 & 0.099 & 120,122 & 0.082 & $-18,084$ & $-13.1 \%$ \\
\hline $\begin{array}{l}\text { Depression } \\
\text { (psychotic and } \\
\text { non-psychotic } \\
\text { affective disorders, } \\
\text { excluding BAD) }\end{array}$ & & & 129,198 & 0.090 & 108,154 & 0.074 & $-21,044 *$ & $-16.3 \% *$ \\
\hline $\begin{array}{l}\text { Bipolar affective } \\
\text { disorder (psychotic } \\
\text { and non-psychotic } \\
\text { cases) }\end{array}$ & & & 12796 & 0.009 & 11,968 & 0.008 & $-828 *$ & $-6.5 \% *$ \\
\hline $\begin{array}{l}\text { Neurotic, stress- } \\
\text { related and } \\
\text { somatoform } \\
\text { disorders (F4) }\end{array}$ & 564,772 & 0.393 & 499,719 & 0.350 & 403,094 & 0.275 & $-161,678$ & $-28.6 \%$ \\
\hline $\begin{array}{l}\text { Organic non- } \\
\text { psychotic mental } \\
\text { disorders }\end{array}$ & 895,545 & 0.623 & 952,809 & 0.667 & 965,368 & 0.658 & 69,823 & $7.8 \%$ \\
\hline Dementia, total & 138,580 & 0.096 & 177,016 & 0.124 & 181,751 & 0.124 & 4,735 & $2.7 \%$ \\
\hline Old-age dementia & & & 49,774 & 0.035 & 48,577 & 0.033 & $-1,197$ * & $-2.4 \% *$ \\
\hline Vascular dementia & & & 127,242 & 0.089 & 133,174 & 0.091 & 5,932 * & $4.7 \% *$ \\
\hline
\end{tabular}

*An asterisk indicates a comparison with 2010; in other cases, it indicates comparison with 2005

form, rather than deleting or rewording it (28\%). Only $11 \%$ of respondents supported a more generalized wording of the criteria (similar to the DSM criteria) than in the ICD-10 schedule; $68 \%$ of respondents were against this because of possible loss of specificity.

The greatest differences among the survey participants were found in relation to the diagnostic significance of negative symptoms, with $51 \%$ of respondents recognizing negative symptoms as obligate symptoms of schizophrenia, and $46 \%$ considering otherwise.
When asked about the use of other diagnostic criteria (in addition to ICD-10) and classifications of schizophrenia in their practice, $19 \%$ of respondents noted that they use only ICD-10 (clinical version); ${ }^{12}$ the remaining respondents indicated that they use other classifications and criteria in their work; clarifications were given in free form as comments. Thus, $49 \%$ of respondents (398 people) indicated that they use Snezhnevsky's classification of schizophrenia (noting, in their comments, that the approach of A.V. Snezhnevsky is more familiar to them 
than ICD-10, since it is simple, logical and prognostically accurate), followed by the criteria of E. Bleuler (32\%), criteria of K. Schneider (30\%), DSM-IV (20\%) and DSM-5 (11\%); other versions of the ICD-10 Diagnostic Guidelines (for example, the research version, multiaxial classification of childhood and adolescent psychiatric disorders) were $13 \%$ each.

A proportion of respondents (20\%) noted that, at least sometimes, they diagnose schizophrenia in patients who do not meet the ICD-10 criteria for schizophrenia in order to justify the disability group they require and to ensure that such patients receive subsidized medicines.

\section{DISCUSSION}

For more than 40 years, since the development of DSM-III in 1980, the issue of the reliability of psychiatric disorder diagnosis has been a keynote idea in the topic of improving the classifications of mental disorders and diagnostic guidelines for these. However, in practice, diagnoses of mental disorders are made in the context of closed interactions between a doctor and a patient, which are difficult to penetrate from the outside. It is also difficult to assess the qualities of such exchanges.
Comparisons of national statistics and the results of epidemiological studies can provide important information about differences between the implicit diagnostic algorithms used by practitioners and structured (or semi-structured) tools used in scientific research, which ensure accurate adherence to diagnostic guidelines. However, such comparison definitely has certain methodological limitations. Thus, the low frequency of diagnosing certain mental disorders, as highlighted in this article, may be associated with several reasons other than the peculiar diagnostic preferences of doctors.

Firstly, the statistical reports reviewed ${ }^{2,3,9}$ include data from state psychiatric institutions only. Notwithstanding the fact that most psychiatrists in Russia work in these institutions, psychiatric care is also provided in some departmental institutions that are not subordinate to the Ministry of Health (for example, in military hospitals, private clinics and by individual practising psychiatrists, the numbers of which have been increasing in recent years), data on whose results are not included in the national statistics. Moreover, some mild anxiety disorders and mood disorders can be treated by doctors of other medical specialties. In this regard, it can be assumed

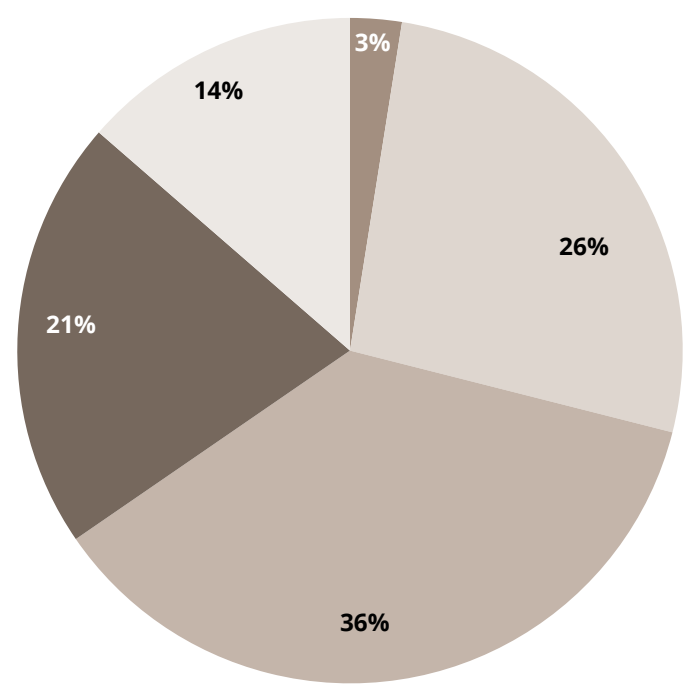

Not using

Use in a general way; do not check criteria

Sometimes check criteria

Often check criteria

Always check criteria

Figure 1. Practical use of general diagnostic criteria for the F20 category (schizophrenia) by respondents $(n=639)$ who simultaneously a) use the ICD-10 diagnosis codes; b) in the year prior to the survey, had diagnosed new patients with psychotic disorders 
that a certain number of people with depression, anxiety disorders and dementia did not seek help from the state psychiatric service during the period studied but might have received the necessary treatment from doctors of other specialties (for example, general practitioners). However, people with severe mental disorders in Russia are mainly observed in state psychiatric units and institutions. In this regard, it can be assumed that, at the very least, persons with BAD (especially BAD type I) and childhood autism are likely to have applied to state psychiatric units and institutions but unlikely to have received proper diagnoses and treatment there.

Secondly, data on registered illnesses depend on the population's access to medical care. It can be assumed that many Russians with mental disorders do not seek psychiatric help on their own due to the stigmatization of mental disorders, the low availability of information about the clinical picture of mental disorders, and lack of up-to-date methods to treat them.

Thirdly, the actual incidence of mental disorders may vary in different countries, and no qualitative epidemiological studies of the prevalence of specific mental disorders in Russia have been conducted in recent decades. However, there is no reason to believe that there are any specific conditions in Russia that would lead to such significant differences in the actual incidence of mental disorders (as identified above). Some of the mental disorders considered are mainly determined by genetic causes. Thus, schizophrenia, bipolar disorder and childhood autism are more than $80 \%$ determined by genetic causes. ${ }^{13}$ In many respects, a genetic predisposition towards these disorders is common with schizophrenia, ${ }^{14}$ and there is no reason to believe that the population of Russia has the same genetic predisposition to schizophrenia as the population of other countries but is completely different in relation to bipolar affective disorder and childhood autism. Recurrent depression and anxiety disorders are less determined by genetic predisposition $^{13}$ and more by unfavourable lifestyle factors. In terms of the number of the latter, it is most likely that the population of our country is not in a more favourable situation than the residents of the United States and western Europe.

Taking into account the above limitations, and having analysed differences in the frequency of diagnosing disorders, we can evaluate the specifics of diagnostic preferences shown by Russian psychiatrists. In addition to schizophrenia, all the disorders included in the comparison were, by an order, less frequently diagnosed by the state psychiatric service than would be expected, based on epidemiological data. Schizophrenia is a positive exception. How can this exception be explained? Unfortunately, it could be caused by over-diagnosing of schizophrenia. Many people with BAD and childhood autism could receive a diagnosis of schizophrenia (and receive relevant treatment), instead of correct diagnoses. The results of the online survey may partially confirm this thesis. When making a diagnosis of schizophrenia, many clinicians are guided not by state-of-the-art international diagnostic criteria, but by outdated approaches, often involving extensive and subjective diagnosis. In addition, according to the survey, some doctors intentionally diagnose schizophrenia in patients with other mental disorders because a diagnosis of schizophrenia implies the possibility of receiving better social care and free medication.

Indirect confirmation of the importance of diagnostic preferences is provided by the dynamics of diagnosing childhood autism in Russia. This category has only been distinguished in national statistics since 2015, when 17.8 thousand people with a diagnosis of autism $(0.0122 \%$ of the population) turned to the psychiatric service. ${ }^{15} \mathrm{At}$ the same time, the Russian Ministry of Health launched a campaign to provide additional training for psychiatrists in the diagnosis of autism, and in 2019, 36.6 thousand people $\left(0.025 \%\right.$ of the population) were registered, ${ }^{2}$ thus showing a $105 \%$ increase over four years.

The dynamics of the registered incidence rate between 2005 and 2019 indicate that significant changes in the diagnostic approaches of doctors occurred only in relation to the diagnosis of childhood autism, while the diagnostic tendencies with regard to other mental disorders reviewed remained unchanged. Moreover, the number of patients with depressive and anxiety disorders in the psychiatric service decreased, and the number of people with organic non-psychotic disorders increased.

Special consideration should be given to the category of organic non-psychotic disorders, which is very popular among Russian psychiatrists. (Almost every fourth person among those who sought psychiatric help in 2019 received diagnoses from this category.) There are no studies focused on the epidemiology of disorders from this category; moreover, the section for "organic" mental disorders was intentionally excluded from DSM-5 
and ICD-11 classifications ${ }^{16}$ due to the fact that the concept of "organic" does not give a clear explanation for the occurrence of a mental disorder (while "organic", structural changes in the brain are currently identified in most mental disorders, including schizophrenia, which was previously considered a functional disorder). It can be assumed that a significant number of people who sought medical care for anxiety, affective disorders or autism received a diagnosis from any of these categories due to the diagnostic traditions of doctors, who tend to explain the appearance of psychopathological symptoms by the hypothetical presence of any hidden, non-specific "organic" changes in the brain. The fact of prevalence of dementias caused by vascular diseases of the brain over dementias caused by neurodegenerative diseases, such as Alzheimer's disease, is also unusual. This is perhaps due to the tradition of revealing "vascular" causes of dementia in all people who have certain cardiovascular diseases.

The survey of psychiatrists demonstrated widespread, but largely perfunctory, use of ICD-10 by psychiatrists in our country. Respondents noted the low practical utility of the ICD-10 Diagnostic Guidelines for the schizophrenia section. This may perhaps explain the fact that only a small percentage of respondents reported regularly using the ICD-10 Diagnostic Guidelines in their work, which, in turn, can lead to inaccurate adherence to the principles laid down in the guidelines. On the other hand, despite the lack of usability, most respondents indicated that they were not ready to abandon the detailed criteria provided in ICD-10 due to fears of reducing the diagnostic specificity.

The survey revealed significant differences in ideas about "correct" diagnosis of schizophrenia, with one half of the respondents being guided mainly by the traditional approach (in line with the views of Kraepelin-Bleuler-Snezhnevsky) and the other half by approaches similar to the ICD-10 guidelines.

Unfortunately, taking into account the above, it can be assumed that a significant number of Russian psychiatrists do not use state-of-the art international diagnostic criteria in the diagnosis of mental disorders, which may interfere with the use of evidence-based treatment algorithms, negatively affecting the quality of psychiatric care. The use of different diagnostic principles by psychiatrists in Russia, among other things, can create a lack of trust in the diagnostic conclusions of their colleagues.

\section{CONCLUSION}

The analysis of national statistics shows that at least some of the diagnostic categories are being used by Russian psychiatrists, though not quite as provided for by the ICD-10 guidelines. Despite possible distortions associated with collection of statistical data, the number of patients seeking medical care and actual differences in the incidence rate, it is safe to say that bipolar affective disorder, depression, anxiety disorders, autism and dementia in Alzheimer's disease, in Russia, are diagnosed by psychiatrists much less often than they should be. Instead of the above disorders, diagnoses of organic nonpsychotic mental disorders and schizophrenia may be used unreasonably often.

The results of the online survey also indicate largely perfunctory use of the ICD-10 Diagnostic Guidelines in our country. In addition, the low estimates given by survey participants regarding usability of the ICD-10 diagnostic criteria for schizophrenia (and the correspondence with the patients they observe in their clinical work), together with a large percentage of doctors who do not directly use diagnostic schedules in their practice, support the need to improve the practical utility of the diagnostic guidelines in the latest revision of the ICD, including, possibly, simplifying, generalizing and adapting it to the diagnostic capabilities in real clinical practice. In light of the upcoming transition to ICD-11, and in order to unify approaches to the diagnosis of mental disorders in our country, educational programmes for psychiatrists should be updated and improved, and the system of continuing medical education should be implemented more actively and widely.

\section{Correspondence to:}

\section{Ivan A. Martynikhin}

ivan.martynikhin@gmail.com

\section{For citation:}

Martynikhin IA. The use of ICD-10 for diagnosing mental disorders in Russia, according to national statistics and a survey of psychiatrists' experience. Consortium Psychiatricum. 2021;2(2):35-44. doi: 10.17816/CP69

\section{Refetences}

1. «O perekhode organov i uchrezhdenii zdravookhraneniya Rossiiskoi Federatsii na mezhdunarodnuyu statisticheskuyu klassifikatsiyu boleznei i problem, svyazannykh so zdorovsem, X peresmotra». 1997. Accessed April 21, 2021. https://docs. cntd.ru/document/9045366 
2. Kazakovtsev BA, Demcheva NK, Yazdovskaya AV, Sidoryuk OV, Nikolaeva TA. Psikhiatricheskaya pomoshch' naseleniyu Rossiiskoi Federatsii v 2019 godu: Analiticheskii obzor. FGBU «NMITsPN im. V.P. Serbskogo» Minzdrava Rossii; 2020.

3. Kekelidze ZI, Kazakovtsev BA, eds. Epidemiologicheskie pokazateli i pokazateli deyatel'nosti psikhiatricheskikh sluzhb v Rossiiskoi Federatsii (2005-2013 gg.): Statisticheskii spravochnik. FGBU «FMITsPN im. V.P.Serbskogo» Minzdrava Rossii; 2015.

4. Saha S, Chant D, Welham J, McGrath J. A systematic review of the prevalence of schizophrenia. PLoS Med. 2005;2(5):e141. doi:10.1371/journal.pmed.0020141

5. Clemente AS, Diniz BS, Nicolato R, et al. Bipolar disorder prevalence: a systematic review and meta-analysis of the literature. Braz J Psychiatry. 2015;37(2):155-161. doi:10.1590/15164446-2012-1693

6. Ferrari AJ, Somerville AJ, Baxter AJ, et al. Global variation in the prevalence and incidence of major depressive disorder: a systematic review of the epidemiological literature. Psychol Med. 2013;43(3):471-481. doi:10.1017/S0033291712001511

7. Steel Z, Marnane C, Iranpour C, et al. The global prevalence of common mental disorders: a systematic review and metaanalysis 1980-2013. Int J Epidemiol. 2014;43(2):476-493. doi:10.1093/ije/dyu038

8. Baxter AJ, Brugha TS, Erskine HE, et al. The epidemiology and global burden of autism spectrum disorders. Psychol Med. 2015;45(3):601-613. doi:10.1017/S003329171400172X
9. Demcheva NK, Kekelidze ZI, Kazakovtsev BA, Makushkin EV. Dynamics of the general and primary incidence of mental disorders in the population of the russian federation aged 60 and older in 2000-2016. Russian journal of psychiatry. 2017;(4):4-12.

10. Ferri $C P$, Prince $M$, Brayne $C$, et al. Global prevalence of dementia: a Delphi consensus study. Lancet. 2005;366(9503):2112-2117. doi:10.1016/S0140-6736(05)67889-0

11. Neznanov NG, Martynikhin IA, Mosolov SN. Diagnostika shizofrenii v rossii: rezul'taty onlain-oprosa vrachei-psikhiatrov chast' 1. Ispol'zovanie MKB-10. Sovremennaya terapiya psikhicheskikh rasstroistv. 2019;(1):2-13. doi:10.21265/PSYPH.2019.24.24.001

12. World Health Organization. The ICD-10 Classification of Mental and Behavioural Disorders: Clinical descriptions and diagnostic guidelines. WHO; 1992.

13. Burmeister M, McInnis MG, Zollner S. Psychiatric genetics: progress amid controversy. Nat Rev Genet. 2008;9(7):527-540. doi:10.1038/nrg2381

14. Craddock N, Owen MJ. The Kraepelinian dichotomy - going, going... but still not gone. Br J Psychiatry. 2010;196(2):92-95. doi:10.1192/ bjp.bp.109.073429

15. Kazakovtsev BA, Demcheva NK, Sidoryuk OV, Tvorogova NA, Pronina LA. Current state of mental health services and the prevalence of mental disorders in the russian federation in 20132015. Psikhicheskoe zdorov'e. 2016;14(7):3-22.

16. Sachdev P, Andrews G, Hobbs MJ, Sunderland M, Anderson TM. Neurocognitive disorders: cluster 1 of the proposed meta-structure for DSM-V and ICD-11. Psychol Med. 2009;39(12):2001-2012. doi:10.1017/S0033291709990262 